\title{
NEW DATA ON DRABA SILIQUOSA (BRASSICACEAE) IN POLAND
}

\author{
Zbigniew MireK ${ }^{1} \&$ AnNa Delimat
}

Zbigniew Mirek, Institute of Botany, Polish Academy of Sciences, Lubicz 46, 31-512 Kraków, Poland; e-mail: z.mirek@botany.pl Anna Delimat, Institute of Nature Conservation, Polish Academy of Sciences, Al. Mickiewicza 33, 31-120 Kraków, Poland; e-mail:delimat@iop.krakow.pl

Draba siliquosa $\mathrm{M}$. Bieb. belongs to a group of four closely related species known from European and Asiatic mountains (Buttler 1967; Walters \& Akeroyd 1993). Besides D. siliquosa, the group comprises D. dubia Suter, D. kotschyi Stur and D. tomentosa Clairv. Three of them (D. dubia, $D$. siliquosa, D. tomentosa) are diploids $(2 \mathrm{n}=16)$ and D. kotschyi is tetraploid (e.g., Buttler 1967; Walters \& Akeroyd 1993; Marhold et al. 2007). Other European species of the genus Draba have been found to be also octoploids (Buttler 1967). Draba siliquosa was reported in some European floras as D. carinthiaca Hoppe, D. glabrata (W. D. J. Koch) Simonk., D. johannis Host or some other names (e.g., Buttler 1967; Kotov 1979). The complex is still insufficiently known and needs further taxonomic work. Just recently a new species of the D. siliquosa complex, D. orientalis Karabacak \& Behçet, was described from Turkey (Karabacak \& Behçet 2009).

The three diploid species, D. dubia, D. siliquosa and D. tomentosa, have a wide Eurasiatic distribution; only Draba kotschyi has a very small range confined to the Southern and Eastern Carpathians, and as such is treated as an endemic species of this area (Jordon-Thaden et al. 2013). Two of the three others have been reported from Central Europe, including Poland (Walters \& Akeroyd 1993). Draba siliquosa is known as an Eurasiatic species occurring in alpine mountains from the Pyrenees, to the Alps, Carpathians, Balkan

\footnotetext{
Corresponding author
}

Peninsula, Caucasus, Pontic Mountains in Turkey and three isolated localities in northern and northwestern Iran (Peniašteková \& Kliment 2002; Delimat \& Borucki 2008, 2009; Noroozi et al. 2011). Up to the beginning of the $21^{\text {th }}$ century the species was unknown from Poland, which is situated at its northernmost limit. In 2008 and 2009, D. siliquosa was reported for the first time from the Polish part of the Tatras (Western Carpathians) by Delimat and Borucki (2008, 2009). It was found on Żabie Mt. at ca $1800 \mathrm{~m}$ a.s.l. The population consisting, of $c a 50$ individuals, was confined to a very small patch totalling $6 \mathrm{~m}^{2}$ on a rocky slope. In 2013 we found a new northernmost stand, also in the Polish Tatra Mts, on the summit of Turnia nad Dziadem Mt. (Wołoszyn Massive) at $1900 \mathrm{~m}$ a.s.l. The population there is of very similar size, $c a 30$ individuals distributed on $c a 20 \mathrm{~m}^{2}$. These two are the only localities known from the High Tatras. Another few very closely situated micro-localities are outside of the High Tatras in the western part of the Belianske Tatras ca $10 \mathrm{~km}$ distant (Feráková et al. 1999 and references therein).

At the newly discovered locality, $D$. siliquosa occurs on mylonitized granitic rock in open places exposed to the south, southeast and southwest. The species is accompanied by plants representing both calcareous and siliceous grassland (Seslerietalia variae Br.-B1. 1926 and Caricetalia curvulae Br.-B1. in Br.-B1. \& Jenny 1926) and other habitats (Androsacion vandelii $\mathrm{Br}$-Bl. in $\mathrm{Br}$--Bl. \& Jenny 1926, Androsacion alpinae Br.-Bl. in Br.-Bl. \& Jenny 1926, Potentillion caulescentis 
Br.-Bl. in Br.-Bl. \& Jenny 1926). Some of the species accompanying $D$. siliquosa are rare or very rare in the Tatra Mts (Saussurea pygmaea (Jacq.) Spreng., Gentiana nivalis L., Saxifraga hieraciifolia Waldst. Kit.); the others are more or less frequent [Agrostis rupestris All., Anemone narcissifolia L., Anthoxanthum alpinum Á. Löve \& D. Löve, Avenula versicolor (Vill.) M. Lainz, Bartsia alpina L., Botrychium lunaria (L.) Sw., Campanula polymorpha Witasek, Cardaminopsis arenosa subsp. borbasii Zapał., Carex sempervirens Vill., Doronicum clusii (All.) Tausch, Euphrasia tatrae Wettst., Festuca airoides Lam., F. tatrae (Czakó) Degen, F. versicolor Tausch, Gentiana germanica L., G. nivalis L., Geum montanum L., Gymnadenia conopsea (L.) R. Br., Hieracium alpinum L., Huperzia selago (L.) Bernh. ex Schrank \& Mart., Hypochoeris uniflora Vill., Leontodon pseudotaraxaci Schur, Luzula spicata (L.) DC., Minuartia sedoides (L.) Hiern, Mutellina purpurea (Poir.) Thell., Pedicularis oederi Vahl, P. verticillata L., Phyteuma orbiculare L., Poa alpina L., P. laxa Haenke, Primula minima L., Pulsatilla alba Rchb., Ranunculus glacialis L., R. oreophilus M. Bieb., R. pseudomontanus Schur, Rhodiola rosea L., Saxifraga paniculata Mill., Silene acaulis (L.) Jacq., Soldanella carpatica Vierh., Solidago alpestris Waldst. \& Kit., Swertia perennis L., Thymus sp., Traunsteinera globosa (L.) Rchb., Veronica aphylla L.].

In reporting this new finding we want to stress its northernmost localization and the phytogeographical importance of the finding. The extreme rarity of Draba siliquosa in the whole Western Carpathians and the smallness of its populations means that it is seriously threatened in this part of the range. The authors of regional (Slovak, Polish, Carpathian) 'Red Data Books' listed D. siliquosa as one of the most endangered elements of the flora (Čeřovský et al. 1999; Mirek \& Piękoś-Mirkowa 2008; Kaźmierczakowa et al. 2014). A similar threat status is accorded it in the easternmost marginal part of the distribution in Iran (Noroozi et al. 2011).

ACKNOWLEDGEMENTS. We are grateful to the authorities of Tatra National Park and the Polish Ministry of
Environment for permission to do research in the strict reserves of Tatra National Park, and to the anonymous reviewers for helpful remarks and suggestions on the manuscript. This work was financially supported by the National Science Centre (NCN, grant no. N N304 276440, 'Ecogeographical and phylogeographical analyses of the mylonite phenomenon in the vascular plant flora of the Tatra Mts').

\section{REFERENCES}

ButTLER K. P. 1967. Zytotaxonomische Untersuchungen an Mittel- und Südeuropaischen Draba-Arten. Mitt. Bot. München 6: 275-362.

Čeřovský J., Feráková V., Holub J., Maglocký Š. \& ProCHAZKÁ F. (eds), Červena Kniha ohrozených a vzácnych druhov a živičichov SR a ČR. 5, Vyššie rastliny. Príroda, Bratislava.

Delimat A. \& Borucki T. 2008. Głodek karyntyjski Draba siliquosa M. Bieb. In: Z. Mirek \& H. Piękoś-Mirkowa (eds), Czerwona Księga Karpat Polskich. Rośliny Naczyniowe, pp. 146-147. Instytut Botaniki im. W. Szafera PAN, Kraków.

Delimat A. \& Borucki T. 2009. Draba siliquosa (Brasicaceae) in the High Tatras. Fragm. Florist. Geobot. Polonica 16(1): 39-44 (in Polish with English summary).

Feráková V., Chrtek J. \& Kochjarová Z. 1999. Draba siliquosa M. Bieb. In: J. ČEŘOvSKÝ, V. FERÁKovÁ, J. Holub, Š. Maglocký \& F. ProchazkÁ (eds), Červena Kniha ohrozených a vzácnych druhov a živičichov SR a ČR. 5, Vyššie rastliny, p. 136. Príroda, Bratislava.

Jordon-Thaden I. E., Al-Shehbaz I. A. \& Koch M. A. 2013. Species richness of the globally distributed, arctic-alpine genus Draba L. (Brassicaceae). Alpine Botany 123: $97-106$

Karabacak O. \& Behçet L. 2009. Draba orientalis (Brassicaceae), a new species from Turkey. Ann. Bot. Fenn. 46: $447-450$.

KaŹmiercZakowa R., Zarzycki K. \& MireK Z. (eds) 2014. Polish Red Data Book of Plants. Pteridophytes and flowering plants. (Third edition revised and expanded). Institute of Nature Conservation, Polish Academy of Sciences, Cracow (in Polish with English summary).

Koтоv M. I. 1979. Brassicaceae (Cruciferae) - Krestnotzvetnye. In: A. Fedorov (ed.), Flora evropeyskoy chasti SSSR. 4: 30-148. Nauka, Leningrad.

Marhold K. Mártonfi P., MerĎa P. Jun. \& Mráz P. (eds) 2007. Chromosome number survey of the ferns and flowering plants of Slovakia. VEDA, Bratislava.

Mirek Z. \& PięKoś-Mirkowa H. (eds) 2008. Red Data Book of the Polish Carpathians. Vascular plants. W. Szafer 
Institute of Botany, Polish Academy of Sciences, Kraków (in Polish with English summary).

Noroozi J., Pauli H., Grabherr G. \& Breckle S.-W. 2011. The subnival-nival vascular plant species of Iran: a unique high-mountain flora and its threat from climate warming. Biodiversity \& Conservation 20: 1319-1338.

Peniašteková M. \& Kliment J. 2002. Draba L. In: K. Golia-
ŠOvÁ \& H. ŠIPOŠOvÁ (eds), Flóra Slovenska. 5(4): 500-540. VEDA, Bratislava.

Walters S. M. \& Akeroyd J. R. 1993. Draba L. In: T. G. Tutin, N. A. Burges, A. O. Chater, J. R. Edmondson, V. H. Heywood, D. M. Moore, D. H. Valentine, S. M. Walters \& D. A. WebB (eds), Flora Europaea (2nd ed.). 1: 372-377. Cambridge University Press, Cambridge.

Received 6 December 2014 